\title{
The Colour of Rhetoric in the Contemporary Agora
}

\author{
Neal Waddell and Bernard McKenna \\ University of Queensland Business School \\ n.waddell@uq.edu.au / b.mckenna@uq.edu.au
}

\begin{abstract}
Rhetoric has three colours: white, black, and grey. White rhetoric is the Grecian Agoric ideal and black rhetoric is its mockery in the form of cheap point-scoring and open deceitfulness. Both are commonly used and obvious. A third, grey, rhetoric, however, is the most pervasive and devious kind of rhetoric in contemporary political discourse, which has developed in response to changing patterns of journalistic inquisition in the 24/7 news and public affairs era. This paper describes the three types of rhetoric, and argues that the Fourth Estate has an important democratic role in counteracting black and grey rhetoric.
\end{abstract}

\section{Introduction}

Rhetoric has three colours: white, black, and grey. White rhetoric is the Grecian agoric ideal and black rhetoric is its mockery in the form of cheap point-scoring and open deceitfulness. Although both are present in political discourse, grey rhetoric has emerged as a pervasive and devious kind of rhetoric in contemporary political discourse [This is described more fully in Waddell and McKenna (forthcoming)]. White, or agoric, rhetoric is a deliberative rhetoric: that is, it was originally developed as purposeful, and incorporated persuasive techniques, and reasoned argument to urge a specific action. On the other hand, black rhetoric is meanspirited, negatively emotional, and not focused on action. Grey rhetoric is mere words, ritualized, abundant, and unproductive.

Developing a taxonomy of political rhetoric is necessary if we are to salvage the crucial Fourth Estate role originally assigned to the media in 1828 by Thomas Babbington Macaulay. Macaulay saw this watchdog role over the other three estates, that is, the judiciary, the Parliament, and the Executive Government as essential to democracy. 
Political utterances are frequently referred to pejoratively as rhetoric, or specifically, mere rhetoric. Two examples of such usage are:

A small military contribution makes Howard's talk of commitment mere rhetoric (Maley, 2004).

Americans, whether Obama supporters or not, knew it [that the Democrats are better able to lead America] was not mere rhetoric (The world needs America to choose Obama, 2008, November 1).

Even some academic commentaries use mere rhetoric to criticize (Schnee, 2001; Hurd, 2002). Dasenbrock (1987: 292) classifies the rhetoric commonly used by politicians in two forms: "political rhetoric...words whose meaning we should inspect very carefully because we are highly suspicious of their utterer's motives" and "mere rhetoric...words which mean nothing". This division parallels the distinction between Plato's attack on rhetoric's abrogation of truth, and Locke's suspicion of superficial language (Dasenbrock, 1987). Noting this, political rhetoric may be a pejorative term either because politicians are held in almost universally low public esteem (Buer, 2002; Pusey, 1997; Ridley, 1998; Steinfels, 2000), and distrusted (MacIntyre, 2001; Ryan, 2003), or because of the superficiality of political language.

Recognizing this pejorative freight borne by rhetoric in general, this paper categorizes the rhetoric in political interviews into different colours to acknowledge these multiple denotations. We argue that the popular pejorative use of rhetoric largely means what we call grey rhetoric, words of little intent, and so, no longer connoting the Aristotelian ideal. For example, criticism of political speak as mere rhetoric (Pockley, 2002), language artifice (Gottliebsen, 2001), or euphemism (Boulton, 2001; Levin, 2002) is common.

\section{Media Interviews as Agoric}

Fundamental to the $24 / 7^{1}$ news age is the media interview. Given that this is where rhetoric is primarily played out, it deserves at least brief attention as a genre. As a genre it is characterized as involving the interviewee and an interviewer, who is not authorized to argue, debate, or criticize (Heritage and Roth, 1995); a "formal, institutional turn-taking system that makes questioning the central activity for participants' conduct," (Roth and Olsher, 1997: 8); and is designed for an overhearing audience (Bull, 1998; Heritage, 1985). Although, initially, broadcast interviews were created to elicit facts (Adkins, 1992; Heritage, 1985), they became more investigative as interviewees were "pursued, challenged, probed, and where necessary... [answers were] clarified and reformulated" (Heritage, in Adkins, 1992: 38). In other words, the features of the genre changed; in some instances, to the extent that new genres emerged (Adkins, 1992; Heritage and Greatbatch, 1991). However, given television's commercial imperative, television news and public affairs is increasingly showing the pressure to be a form of entertainment (Comrie, 1999; Franklin, 1997; Holtz-Bacha and Norris, 2001; Hvitfelt, 1994; Just and Levine, 2001; Machill, 1999; Mander, 1999). This means that politicians are likely to develop two dramatic vulnerabilities. Firstly, they have to 'face-off' against investigative journalists in truth programs; and secondly, they undergo this inquisition in the theatre (particularly) of television controlled by a producer with a 
variety of production techniques. This generates a continual tension for control within an interview as the interviewer seeks to create an entertaining spectacle by casting political players as good or bad, or where a politician's ineptitude presents a sort of entertainment. The tension between news and human interest, information and entertainment, or hard and soft news has traditionally troubled media theorists (Bird and Dardennes, 1988). From the 1950 s, politics embarked on a new era associated with the relatively new phenomenon of television that was reluctant to accept long-winded public debates and where audiences were introduced to the new succinct sound grab (Schulberg, 1957), later to be dubbed the electronic media sound-bite.

Conversely, politicians have attempted to harness the power of television to "market" their politics, like Wallace and "segregation" in the 1960s (O'Dair, 2000: 220), and Dole versus Reagan in the 1970s (Levasseur and Dean, 1996). This theatre needs careful management by politicians and their staff. To avoid being cast negatively or being seen as inept, most politicians now employ media training and a spin-doctoring team of media advisers (Ashley, 2001; Mooney, 2000). A major effect of this mistake-avoidance approach to political interviews is that the television spectacle can become, for many, uninteresting viewing because it presents little information and virtually no entertainment. This, in turn, has spawned a range of interview genres such as the spontaneous door-stop interview, the prearranged door-stop, the formal media conference, the one-on-one television or radio interview, and the mise-en-scène interview where a politician's pre-recorded words are mixed through an interpretive narrative along with pictures and other textual insertions that represent an assortment of views. This last genre particularly requires the public to trust in the media as the Fourth Estate because of its narrative construction. Notwithstanding this, each genre, to different degrees, is produced through the choice of topic; its angle; what pre-recorded text is used; and the placement, timing, juxtaposition and contextualization of the story. Success in each of these genres often depends on 'sound-bite' raw material and entertainmentization for a society flooded with images, slogans and other "bits" of information that impoverish political debate (Scheuer, 2001:3,8). Such a format increases the viewers' dependence on the fairness of the reporter in assembling the material. In media interviews, where usable excerpts are located within a format, usually a narrative, and framed for the viewer from a particular angle that can encourage support or disapproval, it is no wonder that politicians provide little polysemic scope. For example, the (then) Australian Prime Minister John Howard while on international business in Athens made a passing comment, described as loose talk that "he could beat Kim Beazley", the Opposition Leader, thus prompting the media to infer that he intended to contest a fifth election as leader (Farr, 2005: 3; Milne, 2005: 9). The throwaway lines became "the Athens declaration" in the context that his deputy was increasingly agitated at not getting his "fair go" such that the political "partnership" was "in tatters" (Kelly, 2005: 15).

The media interview plays an important role in parliamentary democracy. The original ideal of participatory democracy enacted in Classical Greece was centred on the agora as the public sphere (Jenlink and Banathy, 2002). The agora was the ancient arena for "the interrupted discourse of the common good" (Bauman, 1999: 107). Using Habermasian notions, the contemporary agora is that truly public sphere within which democracy is 
cultivated through rational-critical societal discourse (Bright et al., 1999), and where citizens actively debate about politics (Peters, 1990). Ideally, deliberative rhetoric stimulates these debates to an outcome of deliberative democracy. We adopt James Carey's view that, whatever democracy may be, various electronic and print media settings provide a contemporary agora (Lenert, 1998). However, two factors complicate this metaphor. Firstly, because there is no longer a direct oratory to the public, media as the Fourth Estate have an increasingly complex role in providing "checks and balances...in the name of citizenry" (Christians et al., 1987: 44). Secondly, given contemporary "twenty-four-hour-a-day news culture" (Lessig, 2001: 2068), and the proliferating nature of the PR industry and its "spindoctors" (Cohen, 2001: 16; Sheehan, 2003), politicians have developed strategies to circumvent the deliberative process.

\subsection{White Rhetoric}

Pejorative rhetoric has little connection with the noble (Nybakken, 1939), or moral (Burke, 1969) art of speech and persuasion, which arguably reached its zenith within Aristotle's rhetoric (Honeycutt, 2001) and Cicero's De inventione (Kennedy, 1972). From earliest times, rhetoric as a science has been viewed as two different types, that of Isocrates and his school and that of Aristotle and other schools such as the Stoic (Solmsen, 1941: 35). Both shared a belief in the virtuous intentions of classical rhetoric ${ }^{2}$. Notwithstanding the influence of Isocrates, the ancient rhetoric that Aristotle formalized in his Treatise began a tradition that continued with Dionysius, through "the entire range of Cicero's technical discourse", the "Hermagorean half-finished Rhetorica", Quintilian's influential Institutio Oratoria, Tacitus's Dialogus, the compilations of Hermogenes, to the artes of Halm's Rhetores, and Augustine (Sihler, 1920: 205-6), then later, Aquinas. In this tradition, white rhetoric comprises what Aristotle describes as "both desirable...and worthy of praise... (and) both good and also pleasant because good" (Honeycutt, 2001: 1366b). Aristotle and his Peripatetic followers sought to "elevate rhetoric to a subject of philosophical dignity and standing" through which people could seek the good, the useful, the beautiful and the just (Solmsen, 1941: 41): Cicero's De oratore and Quintilian's Institutio were in this tradition. As well as these qualities of virtuosity, sagacity and humanity, white rhetoric seeks to persuade people to action (Honeycutt, 2001, Bk 1[2]) to achieve useful outcomes. It is concrete and specific, rather than vague and abstract (Remer, 1999). Despite this concreteness, though, white rhetoric draws on emotional appeals as necessary to vindicate the claims of truth and justice (quoted in Remer, 1999). Finally, white rhetoric is used by one of good character as a vigorous, logical, persuasive call to action (Cicero, cited in Tinkler, 1995).

These same ideals are found in more recent rhetoric. For example, "new rhetoric" aspires to practical reasoning and argumentation (Frank, 1998: 120; Warnick and Kline, 1992) with a vision of language that is "descriptive, literal, disinterested, clear prose" (Dasenbrock, 1987: 293). Although white rhetoric can be pragmatic-Cicero used his oratory skills to criticize Caesar in a disguised fashion (Dyer, 1990)—we base our notion of white rhetoric on the ancient world because the persuasive argumentation found in the 
Grecian agoras was described and codified by Aristotle as deliberative oratory (Tinkler, 1995). However, in contemporary public spaces, with the omnipresence of news and public affairs programs, deliberation presents different concerns than it did for the agoras.

\subsection{Black Rhetoric}

Barthes' notion of 'black' rhetoric, as a natural, human derivative of ancient rhetoric after it became an institutionalized discourse, is the converse of white rhetoric. Barthes (1988) sees it as a mockery of rhetoric, with suspicions, contempt and irony. Black rhetoric is common in adversarial politics to promote argumentation, conflict, and dispute by simplistic, ready-made dichotomies of right and wrong, or good and bad etc. Such binary oppositions also provide an over-simplification that appeals to journalists (Coleman, 1997) seeking conflict, controversy and scandal (Gardels, 1995), and an adversary (Budiansky, 1995). Black rhetoric_new rhetoricians McGee and Lyne (1987: 383) call it "bad rhetoric" - is ignoble and mean-spirited, sometimes dishonest, and sometimes characterized by gratuitous name-calling or sarcasm and consequently diminishes the language. Another form of black rhetoric is ignoble and mean-spirited discourse particularly in representing a person or groups of people in ways that leave them open to public negative stereotyping or vilification. The third form of black rhetoric is the dishonest statement. In summary, black rhetoric is unnecessarily adversarial; makes grandiose claims; distorts the opponent's position; and is graceless.

\subsection{Grey Rhetoric}

Grey Rhetoric developed in response to changing patterns of journalistic inquisition and the growth of "spin" in the 24/7 news and public affairs era. If black rhetoric is overtly ignoble, the language of grey rhetoric hides below the signifying surface, and so needs more careful analysis. Although grey rhetoric masquerades as something meaningful, it is semantically meaningless: as Bourdieu (1991: 41) says, "statements that are formally impeccable but semantically empty" . By feigning persuasion, a politician merely contributes "to the jabberings of social life" (de Certeau's phrase, 1985: 146). Linguistically, grey rhetoric manifests itself in what Fairclough (1989: 62, 195) calls "synthetic personalization", the primary purpose of which is to establish or maintain social interaction, rather than to convey meaning.

Apart from such meaningless jabbering as 'in due course' and 'the matter is being discussed,' the two most common forms of grey rhetoric are the disingenuous claim and feigned outrage. Typically, political parties in Australia represent themselves disingenuously as the 'underdog' even where they hold a strong lead in the polls. Feigned outrage, a product of adversarial politics, is most often seen in claims of incompetence, dishonesty, and malfeasance. For example, British Labour Party member, Glenda Jackson, and former Minister, Clare Short, repeatedly, but ineffectively 'called on then Prime Minister (Tony Blair) to resign' (Die-Zeit, 2003). This is grey rhetoric because it neither expects to persuade nor does so, yet is a ritualistic form of adversarial speech. Grey rhetoric can be considered 
as dissembling or hedging, or more stylistically as equivocation or prevarication. It involves non-straightforward communication because it appears ambiguous, contradictory, tangential, obscure or even evasive (Bavelas et al., 1990, in Bull, 2000). The public's belief that politicians are evasive under questioning certainly has empirical backing (Bull et al., 1996; Bull and Mayer, 1993).

\section{Corpus and methodology}

To build a corpus for analysis, we enlarged our collection of political rhetoric previously gathered from the database of the Australian Broadcasting Corporation (http://www.abc.net.au/) and added data using mostly Australian newspapers from the Factiva research database of media sources (http://global.factiva.com/sb/default.aspx?NAP $\mathrm{C}=\mathrm{S} \& \mathrm{fcp} i \mathrm{l}=\mathrm{en})$. These include The Age, The Sydney Morning Herald, The Australian, and the AAP newswire service. As search terms, we used locutions commonly associated with political interviews such as "Can I make the point ...", "Let me just say...", or "I really must add...". As well, we searched these media sources for political use of rhetorically charged words such as 'policy', 'announce/ment', 'opposition', 'issue', 'claim', 'dis/honest', 'mis/trust', 'challenge', 'reform', 'fail', 'attack', 'resign', 'abuse', 'mock/ery', 'care/ful', and, of course, 'mere/rhetoric'. We settled on 84 statements that provided a range of possible variations of rhetoric that were appropriate for analysis.

The analysis does not allow for non-verbal aspects of delivery (hypocrisis) and style (lexis) which, since the time of Aristotle's Rhetoric, had been important to the art of oratory (Gunn, 2003). Attention to non-verbal aspects would also allow analysis of intonation, timing, gesture, and other paralinguistic features from a rhetorical perspective (Atkinson, 1984; Heritage and Greatbatch, 1986). We also acknowledge that conversation analysts might also look to the effects of "fragments of talk...hesitations, pauses, overlaps [etc.]" (Potter, 1997: 152) combined with lexical choices "to find meaning and context in interaction" (Heritage, 1997: 162). Notwithstanding these limitations, if we synthesize the discussion so far, there is a set of criteria by which we can classify and evaluate the rhetoric of political interviewees. The ontological basis for categorising was devised by a hermeneutic process of analysing statements and determining their 'fit' in various categories. The best fit was achieved using the categories summarized in Table 1 below. Black, White, and Grey Rhetoric in the horizontal row are characterized according to (in order of priority) a description using the qualities espoused by Aristotle such as virtuosity, sagacity and humanity, as they apply to vigorous, logical, persuasion; by the interviewee's agency and subject position; and the way in which rhetorical tactics of repetition, bridging, and distancing are used. Examples of each are provided. 


\begin{tabular}{|c|c|c|c|c|c|}
\hline \multicolumn{3}{|c|}{ Rhetoric } & \multicolumn{3}{|c|}{$\begin{array}{l}\text { Rhetorical tactics used in each category [with } \\
\text { hypothetical examples] }\end{array}$} \\
\hline Shade & " Description & $\overline{\text { Agent }}$ & Repetition & Bridging & Distancing \\
\hline $\begin{array}{c}\mathbf{W} \\
\mathbf{H} \\
\mathbf{I} \\
\mathbf{T} \\
\mathbf{E}\end{array}$ & $\begin{array}{l}\text { Aristole's } \\
\text { 'noble } \\
\text { cause' } \\
\text { through } \\
\text { persuasion } \\
\text { in political } \\
\text { dialogue or } \\
\text { argumentati } \\
\text { on. Uses } \\
\text { logical } \\
\text { reasoning to } \\
\text { support, or } \\
\text { not } \\
\text { contravene, } \\
\text { humanitaria } \\
\text { n principles. }\end{array}$ & $\begin{array}{l}\text { Speaker } \\
\text { dealing } \\
\text { with a } \\
\text { significant } \\
\text { cause or } \\
\text { issue, } \\
\text { persuading } \\
\text { or } \\
\text { exhorting } \\
\text { for } \\
\text { altruistic } \\
\text { reasons. }\end{array}$ & $\begin{array}{l}\text { Used to } \\
\text { maintain a } \\
\text { central, } \\
\text { 'noble' } \\
\text { message, e.g., } \\
\text { anaphora, 'I } \\
\text { say again, we } \\
\text { believe in } \\
\text { women's } \\
\text { rights, we } \\
\text { believe in } \\
\text { men's rights, } \\
\text { we believe in } \\
\text { human } \\
\text { rights'. }\end{array}$ & $\begin{array}{l}\text { Used to } \\
\text { maintain, or } \\
\text { return to, the } \\
\text { relevance of } \\
\text { the 'noble' } \\
\text { message: e.g., } \\
\text { 'Let me get } \\
\text { back to the } \\
\text { issue of the } \\
\text { loss of human } \\
\text { rights in this } \\
\text { question'. }\end{array}$ & $\begin{array}{l}\text { Might be used } \\
\text { to laud the } \\
\text { status of one's } \\
\text { political office: } \\
\text { e.g., 'The } \\
\text { nation's } \\
\text { Attorney- } \\
\text { General [me] } \\
\text { must always } \\
\text { defend the rule } \\
\text { of law first and } \\
\text { foremost'. }\end{array}$ \\
\hline $\begin{array}{l}\text { B } \\
\mathbf{L} \\
\mathbf{A} \\
\mathbf{C} \\
\mathbf{K}\end{array}$ & $\begin{array}{l}\text { Barthes's } \\
\text { 'mockery of } \\
\text { rhetoric...a } \\
\text { whole } \\
\text { schoolboy } \\
\text { practice', } \\
\text { manipulates } \\
\text { language } \\
\text { using } \\
\text { suspicions, } \\
\text { contempt, } \\
\text { irony for } \\
\text { outcomes } \\
\text { that are } \\
\text { dissembling } \\
\text { or dishonest } \\
\text { e.g., } \\
\text { stupidly } \\
\text { adversarial } \\
\text { politics }\end{array}$ & $\begin{array}{l}\text { Speaker } \\
\text { seeking to } \\
\text { be ritually } \\
\text { partisan or } \\
\text { gaining } \\
\text { opportun- } \\
\text { istic } \\
\text { advantage. }\end{array}$ & $\begin{array}{l}\text { Used to } \\
\text { increase the } \\
\text { 'theatre' of } \\
\text { the occasion } \\
\text { by repeating } \\
\text { the } \\
\text { manipulated } \\
\text { message: e.g., } \\
\text { 'And I tell } \\
\text { you my truth: } \\
\text { he's a joke, a } \\
\text { whole joke, } \\
\text { and nothing } \\
\text { but a joke' }\end{array}$ & $\begin{array}{l}\text { Used to } \\
\text { increase the } \\
\text { 'theatre' by } \\
\text { transferring } \\
\text { from an } \\
\text { interviewer's } \\
\text { topic to the } \\
\text { interviewee's } \\
\text { manipulated } \\
\text { topic: e.g., } \\
\text { 'Let's get to } \\
\text { the real story } \\
\text { in this; this } \\
\text { party would be } \\
\text { hopeless in the } \\
\text { parliament of } \\
\text { Toytown'. }\end{array}$ & $\begin{array}{l}\text { Would be } \\
\text { 'black' when } \\
\text { used, as with } \\
\text { Richard Nixon, } \\
\text { with a higher } \\
\text { level of theatre } \\
\text { or dishonesty: } \\
\text { e.g., 'The Prime } \\
\text { Minister of this } \\
\text { great country } \\
\text { would never lie } \\
\text { to the people' } \\
\text { [if, indeed s/he } \\
\text { had] }\end{array}$ \\
\hline
\end{tabular}




\begin{tabular}{|c|c|c|c|c|c|}
\hline $\begin{array}{l}\mathbf{G} \\
\mathbf{R} \\
\mathbf{E} \\
\mathbf{Y}\end{array}$ & $\begin{array}{l}\text { Engaging in } \\
\text { political } \\
\text { utterances } \\
\text { that } \\
\text { simulate } \\
\text { adversary } \\
\text { but which } \\
\text { may be } \\
\text { disingen- } \\
\text { uous, } \\
\text { perfunctory, } \\
\text { and not } \\
\text { necessarily } \\
\text { persuasive. }\end{array}$ & $\begin{array}{l}\text { Speaker } \\
\text { dealing } \\
\text { with an } \\
\text { issue } \\
\text { ritually, or } \\
\text { minimiz- } \\
\text { ing image } \\
\text { damage. }\end{array}$ & $\begin{array}{l}\text { Becomes } \\
\text { 'grey' when } \\
\text { the repetition } \\
\text { makes the } \\
\text { tactic more } \\
\text { visible than } \\
\text { the substance } \\
\text { it represents: } \\
\text { e.g., 'Let me } \\
\text { repeat once } \\
\text { again, she } \\
\text { should resign } \\
\text { from } \\
\text { politics'. }\end{array}$ & $\begin{array}{l}\text { Used to } \\
\text { transfer away, } \\
\text { or deflect, } \\
\text { from criticism: } \\
\text { e.g., 'We need } \\
\text { to ensure that a } \\
\text { proper process } \\
\text { is in place } \\
\text { before we can } \\
\text { make a } \\
\text { decision'. }\end{array}$ & $\begin{array}{l}\text { Most commonly } \\
\text { used here as a } \\
\text { way of } \\
\text { abrogating } \\
\text { responsibility } \\
\text { for an issue } \\
\text { motivating } \\
\text { criticism: e.g., } \\
\text { 'Anyone who } \\
\text { thinks that } \\
\text { running a five } \\
\text { billion health } \\
\text { system is easy } \\
\text { clearly doesn't } \\
\text { know what } \\
\text { they're talking } \\
\text { about'. }\end{array}$ \\
\hline
\end{tabular}

Table 1. Colours (categories) of rhetoric.

Having a workable system for categorizing political rhetoric, we then separately classified each statement. Following this, we compared our classifications of the 84 items and explained our reasoning. Three outcomes were possible: we could have agreed on classifications of black, white, or grey for the same reasons; for different reasons; or disagreed on classifications. When the latter two occurred, it provided useful information for altering our definition of the classification so that we agreed on our classification for the same reason. This was a useful hermeneutic process that provided greater construct validity for our classification system. For example, the description of black rhetoric in some instances required knowledge about whether a statement was true or not if classified for the reason of being dishonest. Thus, in the example provided in Text 5 below, it was necessary to have the information, which was later admitted, that Senator Evans had lied. Importantly, after discussing our reasons for classification in disputed cases and making necessary alterations to the definition, we were able to achieve unanimity on determining whether a statement represented white, black, or grey rhetoric. From this body of material, we then selected 12 examples of various types of rhetoric for this paper.

\section{Findings}

The robustness of these three rhetorical categories can be demonstrated in their application to 12 instances ( 4 white; 4 black; and 4 grey) below, each of which is individually analysed. 


\subsection{White Rhetoric}

The political figures in these four examples of white rhetoric (Texts 2-5) are not strong leaders with considerable aura. This indicates that nobility of speech is possible even for less significant politicians.

\section{Text 1}

Senator Meg Lees: I don't want to walk [from the Australian Democrats]. I've put 25 years of my life into this party. I very firmly believe in the need for a third force in Australian politics, particularly at federal level to offer an alternative to the two major parties (Kirk, 2002).

Lees overtly draws on her ethos - 25 years commitment to her party — to make her statement of regret more profound and credible. Instead of attacking the party that has dumped her as leader, she affirms her belief in a 'third force' (exhorting), although this clearly may not be the Democrats (a tactful warning).

\section{Text 2}

Colin Barnett (Liberal Party Leader, Western Australia): I would urge Senator Alston to seek some local input from Western Australia before he makes a decision like that [the full sale of Telstra-Australia's largest telecom (part-privitized)]...This decision by the Federal Government is just right out of touch with the reality of Western Australia...I would not be surprised if today's announcement hardens people's resolve against a full Telstra sale ('Regional Aust warming to Telstra sale pitch: Vaile', 2002).

Barnett has little established ethos apart from party leadership to add weight to his argument. As the state leader of the Liberal Party, he has the difficult job of exhorting the Federal Liberal Government not to proceed with the sale of Telstra. The statement's whiteness derives from his call to action against the actions of an established Government keen to make the sale for ideological reasons, his respect for the former minister [Alston] whom he is criticizing, and his identity with society while claiming to speak for its citizens.

Text 3

Chris Schacht (Labor Senator): Once the reforms go through, just as Whitlam showed in the late 1960s, the party got stronger and better and those who opposed him, no one can remember whom they are (Kelly, 2002).

Schacht, like Barnett, is speaking on a contentious intra-party issue, which has the potential for electoral harm if the media were to report the differences as a Labor Party 'split'. By drawing on the iconic Labor patriarch, Whitlam, who led Labor from despair to electoral victory in the 1960s and 1970s, Schacht is exhorting his party to draw the inspiration and courage to do what is necessary to resurrect the party's attractiveness. 
Text 4

Senator Natasha Stott Despoja (Democrats Leader): I see them [John Howard's comments about Democrat's leadership] for exactly what they are, and that's the PM attacking, not so much me personally, but my party...I tell you what, I'm not intimidated by what he says about me and I'm not intimidated, nor is my party, by challenging his policies including the issue of Woomera and mandatory detention (O'Brien, 2002).

When Stott-Despoja uttered these words, not only was her own leadership under attack, but her party was opposing the popular government policy of incarcerating refugees. Thus, she is unable to draw on significant personal status, or ethos. Nevertheless, by claiming that Howard's attack is directed at her party, she is able to position her subject role as party defender, an ennobling role. Furthermore, she casts Howard's 'intimidation' as slightly menacing, further subtly enhancing her nobility.

\subsection{Black Rhetoric}

We have defined black rhetoric as that which uses argument that is disputatious by using simplistic dichotomies and straw-man arguments. Of the following four examples of ignoble black rhetoric (Texts 5-8), only one results from dishonesty. But, as shown earlier, narrative dishonesty is but one of the forms of truth manipulation that debases parliamentary language. Also common are attempts to humiliate opponents.

\section{Text 5}

Gareth Evans (then Labor Foreign Minister): [The claims are] totally baseless, beneath contempt and a disgraceful abuse of Parliamentary privilege (Davis, 2002).

This is a simple case of black rhetoric because Evans lied when rejecting an opposition claim that he was in a sexual relationship with an MP who defected to the Labor Party.$^{3}$ At the time, it could have been grey rhetoric (regulation denial) or white rhetoric (if traduced). However, given that we now know the claims to be true, it is black rhetoric. Importantly, contextual information is vital in this classification.

\section{Text 6}

Bob Quinn, State Liberal Leader [concerning Bill D’Arcy, a former Labor MP convicted of paedophilia]: The episode makes a mockery of Mr Beattie's claim that he had cleaned up his party (Franklin and Griffith, 2002).

The manipulated enthymeme claims that the Premier had not 'cleaned up his party' because a former parliamentarian, belonging to the Premier's Labor Party, who was convicted of a serious paedophile offence, was still listed as a member of the party. Clearly an administrative oversight by the party executive is flimsy evidence for such a claim. If Quinn had qualified his accusation (e.g., 'If this is typical... then...'), or if he had provided more compelling evidence, the statement would not be black because it would be more credible 
and modulated. However, to call the oversight a 'mockery' depreciates the language. This continual depreciation of the language contributes to public cynicism with political 'antics'. A more accurate statement would have been more compelling and would not have deprecated the language: e.g., 'Premier Beattie must be deeply embarrassed to lead a party that has a convicted paedophile, his former Labor colleague, as a party member'. This would position the Labor Premier to deny his embarrassment, rather than the spurious failure to 'clean up' his party.

\section{Text 7}

John Howard (former Prime Minister) [on Labor's border protection policy]: It sends a very clear signal to the Australian public, and to the world, that if you want strong border protection laws in this country, if you want consistency in the national interest, never trust the Australian Labor Party (Kelly, 2002).

This is a marginal black/grey statement. However, it is classified black because the superlative degree of the language is depreciated. The Labor Party's policy in fact differed only in degree from the Liberals, not substantively. The blackness derives from the enthymematic assertion about Labor's supposedly weak border policy and the silly intensifier 'never'. That is, even if the policy were 'weak', would this disqualify Labor forever? By depreciating the language, future attempts to more appropriately censure conduct becomes less effective because of the 'crying wolf' effect on an inured audience.

\section{Text 8}

Gordon Nuttall, Former Queensland Health Minister: I am a very honest person and I genuinely believe there was just a mix-up... Like a front row forward I am just going to keep taking the ball up and I am not leaving the game until it was over (ABC News, 2005, December 7: 8).

This utterance was used to respond to questions about Nuttall's handling of the scandal involving Queensland's "Doctor Death", Jayant Patel, who was linked to the deaths of 17 people at Bundaberg Base Hospital. At first, it appears to contain grey rhetoric with a reasonably inappropriate 'football' metaphor, even verging on white rhetoric as Nuttall declares a 'fight to the end' determination to achieve action. This utterance, however, proved to be dishonest in light of his subsequent resignation from the Health Ministry as he was found to have lied to the Queensland Parliament (Wordsworth, 2005, December 9). At the time that Text 8 was uttered, then Premier, Peter Beattie could be said to have used diversional grey rhetoric in supporting Nuttall with the utterance, 'I have to be honest with you, I think this is a sideshow'. However, if he too were being dishonest, and knew that Nuttall had lied, this would be black rhetoric.

\subsection{Grey Rhetoric}

The overwhelming feature of grey rhetoric, its semantic emptiness, is evident in Texts 9-12. 
Each of the texts exemplifies the various tactics of grey rhetoric: perfunctory statements, feigned outrage, procedural re-casting, and re-nominalising.

\section{Text 9}

John Howard (former Prime Minister): There may be a lot of 'ifs', 'buts' and 'maybes' there [after questions about worth of his European trip] but, in a policy sense, I believe it's a step in the right direction (Yaxley, 2002).

The perfunctory statement is the quintessential semantically bereft statement that fills a verbal space, but contains virtually no substance. Text 9 exemplifies this feature because it could be delivered in response to almost any question. Characteristic of this grey rhetoric is the hackneyed trope such as 'step in the right direction', 'turn the corner', 'down the track', 'moving on' and 'at the end of the day'. The three other types of grey rhetoric are semantically richer.

\section{Text 10}

Gavan O'Connor (former Labor Shadow Minister): The Prime Minister should immediately bring Mr. Tuckey back into line. If he fails to do so, the public is entitled to believe that the Howard Government is soft on drink driving (O'Connor, 2002).

Text 10 is semantically richer because it appears to make a claim. Yet, in the light of experience, such claims almost have little semantic value. This is an archetypal statement of feigned outrage that accompanies a call for a sacking, an inquiry, or a resignation. In this instance, O'Connor manipulates an enthymeme to reason artificially that failing to discipline the minister equates with tolerance of drink driving. Unfortunately, such statements are also symptomatic of a 'cry wolf' syndrome to which the public has become relatively inured. It has lost its power because repetition has caused a loss of credibility.

\section{Text 11 \\ Interviewer: What happened on Melville Island? Did these people ask in that way for Australian assistance and to get asylum? \\ Vanstone: Well look, this question has been put to me before and I have indicated to the media that we would go back, once everybody was back on shore etc, through who said what to whom and when I've got that advice, I'll obviously come back to you. \\ Interviewer: Were Australian soldiers there Senator? \\ Vanstone: Can I make the point? The question of whether these people sought asylum is not relevant to the point of them going back to Indonesia because at all material times they were not in the Australian migration zone, because Melville Island had been excised and in particular when any interviews were done with DIMIA (Department of Immigration and Multicultural and Indigenous Affairs) officials, the boat had been taken back into international waters. (McGrath, 2003).}

Former Minister for Immigration, Amanda Vanstone's responses to the radio interviewer 
exemplifies another form of grey rhetoric, procedural re-casting. This method is based on re-casting a contentious issue into an administrative procedure that needs to run its course, and so avoids any substantive scrutiny of the action itself. Office holders use this deferral mechanism in the knowledge that the story is likely to go stale by the time the relevant information is obtained. In this instance, saying 'we would go back...through who said what to whom' gainsays the very point of the question. That is, there was strong evidence that the Turkish men on the Indonesian boat had claimed refugee status when they were met by Australian Navy officers. UN conventions, to which Australia is a signatory, obliges Australia to host the people until their status is proven. However, this point is lost in a spurious claim of procedure. She also directly avoids the question with the bridging device 'Can I make the point' so that she can present a second procedural deviation, the legal status of the zone in which the action took place (in fact, the re-zoning had been rushed through parliament the night before). The greyness occurs because there is no real dialogical engagement. The politeness of the turn-taking process consistent with this genre is subverted. It is noteworthy that the next day, the government supplemented Vanstone's grey rhetoric with (then) Prime Minister Howard's black rhetoric when he told the media that the Senate's action in reinstating the islands (Hansard, 2003: 17531) showed that 'the Labor Party is soft on border protection' (Tingle, 2003).

\section{Text 12}

Steve Bredhauer (former Queensland Transport Minister): This is not a revenue exercise by the government, it is in fact enabling us to cover the cost of providing services which we are already providing (McKinnon, 2002).

A related form of grey rhetoric is to re-nominalize an unpleasant or unfavourable phenomenon as something more anodyne or fatuous. Bredhauer announces that fees for driver's licences would rise substantially, but fatuously denies that it is 'a revenue exercise', rather than it enables the government to 'cover the cost'. But clearly, if licence fees are 'to cover the cost', then as an indirect tax, they are a form of government revenue raising. Such statements contribute to public cynicism because politicians represent certain things as something that they clearly are not. A variation of this is when something quite negative occurs, but the government represents it as a 'challenge'. To alter this to white rhetoric - that is, to impel action or consent - the (then) minister should have simply acknowledged that the government needed more money to provide their services and called on the public spirit to cope with the extra cost.

\section{Journalists' Responses to Black and Grey Rhetoric}

Because political journalism has such a vital role in the democratic process, it is vital that they counter black and grey rhetoric. Because counteracting these forms of rhetoric is the basis of good investigative journalism, we argue that the often considerable time needed by journalists to operate within increasingly repressive libel laws is essential to democracy. 
However, challenging grey rhetoric is perhaps even more difficult because it is subtle and pervasive in a semiotically crowded $24 / 7$ world. Nonetheless, journalists can successfully reveal grey rhetoric for what it is: an attempt to dissemble or stall. A laudable instance of this was Sky News Reporter, Geoff Mead's interrogation of U.S. Army spokesman, General Vincent Brooks during Gulf War II. General Brooks made a statement to a media conference following the death of Al Jazeera reporter, Tareq Ayoub. The Americans fired on his well-marked newspaper building and also on the Palestine Hotel, known to be housing the foreign press, killing two journalists. Mead questioned him.

\begin{abstract}
Text 13
Mead: Initial reports indicate that the Coalition force operating near the hotel took fire from the lobby of the hotel and returned fire and any loss of life, civilian loss of life or unintended consequences, again, we find most unfortunate and also undesirable.

Brooks: If I can continue on the point you made there. If you're claiming the fire was coming from the lobby of the Palestine Hotel, why was the tank round directed at an upper floor? And what does that kind of marksmanship — or lack of it — suggest about the risks to civilians as your forces penetrate further into Baghdad?

Mead: The response of fire is something that we always have to get more details as time goes on-first, specifically, where the fire was returned and what was hit and where the fire came from. So I may have misspoken on exactly where the fire came from.
\end{abstract}

Following further questioning, Brooks was reduced to a risible response:

Brooks:The action occurs when the action occurs-and everything thereafter is speculative or investigative (Marr, 2003).

Thus, what appeared at first as a reasonable explanation and a white rhetoric expression of condolence for the dead journalists, unravelled with a simple, direct question. Immediately, Brooks retracted a crucial element of his army's defence, and further questioning forced him into thick grey rhetoric.

However, vigorous pursuit of an authentic and truthful answer can sometimes lead to the interviewer being perceived as hectoring and over-zealous or rude and the interviewee receiving audience sympathy. In the following exchange, Four Corners journalist, Liz Jackson, continually interrupts the (then) Prime Minister, Mr Howard. What clearly infuriated the journalist was that the government had recently won an election largely on preventing 'boat people' from landing in Australia to obtain refugee status. A crucial part of that campaign was the government's depiction of the, mostly Afghani, refugees being so inhumane that they actually threw their children into the Indian Ocean. This story gained credence because the newspapers and television stations had been given governmentauthorized pictures of children in the water. It was later revealed by Four Corners - a highly respected public affairs on government funded public television-to be untrue. Jackson provided the story that the photos were, in fact, of people who had leapt off their sinking boat a day after the claimed 'children overboard' incident. Clearly some members 
of the government and/or their staff had lied, yet Howard was trying to say otherwise.

\author{
Text 14 \\ Jackson: But you've indicated that you discussed the photos. \\ Howard: Yes I've indicated...There was an allusion to the debate about, to the \\ discussion about the photographs, yes, I've indicated... \\ Jackson:: Of a doubtful nature? \\ Howard: Look, I just repeat what I've said... \\ Jackson: Well I'd just like to clarify exactly... \\ Howard: No, I, well I'm... \\ Jackson: Was it indicated to you that there was any doubt that they were the wrong \\ photos? \\ Howard: I can only repeat what I've said before. \\ Jackson: Well it's an important issue isn't it? \\ Howard: ...why I'm very careful in what I'm saying, because it is an important issue \\ (O'Regan, 2002)
}

Jackson's relentless questioning breaches interview turn-taking protocol because she interrupts Howard on four occasions before he had completed his sentence. Howard obliquely acknowledges the accusatory threat to his face if shown to be complicit in the lie when he says 'I'm very careful in what I'm saying'. While the responses are clearly evasive, the question is whether they constitute grey or black rhetoric. At one level, Howard's rhetoric is grey because it uses hedging devices and vacuous repetition to avoid a direct answer to seriously threatening questions. The hedging is evident in Howard's initial answer. In particular, he uses an agentless passive opening ('there was') and a vague nominal ('allusion'). Also the repair from 'debate' to 'discussion' obscures the contested nature of the cabinet debate. These, and the repetition of 'I've indicated' and 'I've said', are the mark of a very experienced politician ensuring that nothing substantive is said about the issue. Ultimately, the interviewer was not able to reveal the interviewee's black or white rhetoric to the audience, and no information is adduced. At the level of textual analysis, Howard's responses can be classified only as grey. However, important contextual information places this in the black rhetoric category because it later became evident that the photographs released by the government in the heat of an election campaign did not represent what the government claimed. Undoubtedly, such apparently damaging photographs originally made it virtually impossible for an opposition to argue that such people were worthy of help, and should not be turned away. As it turned out, Howard's 'Pacific Solution' was a significant plank in the conservative's election strategy. Given that the polls showed the electorate to be strongly opposed to the refugees' entry, Howard clearly gained an electoral advantage.

Because untruthfulness in public office, especially when it involves an appalling racial smear, is ignoble, the rhetoric is black. It is abetted by the grey rhetoric in this interview. Although one may criticize the interviewer's incessant interruption (no doubt attempting to block grey rhetoric), she clearly had a role to ensure that politicians respond to the questions 
put to them. However, constantly preventing a response is, we argue, less successful than, say, pointing out that the interviewee has not answered the question. An interviewer might be more effective re-formulating the question, e.g., 'Given that you constantly refuse to answer the question, sir, might our viewers reasonably believe that you are not being completely honest?'. The focus would then be, not on the vacuous grey response, but the cause of this grey rhetoric. Watson (2003), who was speech writer for a former Australian Prime Minister, sees such journalistic challenge as crucial in dissuading people of influence and power from using language intended to deceive and manipulate. He sees a crisis in the often peculiar, debased or dishonest political language because it is blended with the language of the media.

\section{Conclusions}

This study, through its analysis of political rhetoric, has established a case for dividing political utterances into three types of rhetoric: white, grey, and black. Furthermore, we have devised a method for classifying these utterances. This classificatory method, we claim, is valuable for journalism in fulfilling their vital Fourth Estate role in parliamentary democracies.

Parliamentary democracy is fundamental to our democratic process, no matter how flawed it may be. Vital to that process is the communication between aspiring and actual politicians and the electorate, in particular, through the media interview. Ironically, our hypermediated 24/7 news and current affairs programs have helped to induce ambivalence and equivocation - grey rhetoric — in this communication, engendering audience cynicism and distrust. Because endemic cynicism and distrust rust the foundations of the parliamentary structures, the potential for dysfunction in the longer term is real and should be addressed.

Classifying rhetoric must always be done by taking into account the context in which the utterance was made. There may be times when apparently grey rhetoric is used for noble reasons particularly when the politician is motivated to act with concern for the collective or larger interest. To achieve this, politicians may deceive through "noble" or "vital" lies, in the Platonic sense, that they deem necessary to maintain "societal stability" (Meltzer, 2003: 73). Such equivocation has to be "understood within the context of the individual's communicative situation" (Bull, 2000: 222): that is, the potential for direct replies may be limited by the risk of offending a substantial number of voters or by the limited time to answer a complex question. Such problems need to be acknowledged when criticizing vague or ambiguous replies. Other plausible reasons for equivocation, according to Bull (2000), include avoiding criticism of valued people and institutions, or a friendly country when that may be warranted.

We do well to remember the fallibility of politicians as actors in representing community's interest in the playing of democracy. In contrast to Plato's elitist distrust of the community's ability to participate in the process of crafting democracy, Aristotle saw rhetoric as an essential tool in the ethical deliberations of the polis. The Athenic Agora is 
now the metaphor for the public sphere where public affairs are ideally democratically debated and reported on by media as the Fourth Estate (De Luca and Peeples 2002). When these public debates are undertaken in the public sphere-the metaphoric Agora-politicians are bound by rhetoric as an art of persuasion. Some of them will be eloquent; some will suffer agoraphobia within the Agora. Rather than consigning all political discourse to the category of mere rhetoric, we classify rhetoric as a spectrum. This system provides a useful means to quickly identify the quality of discourse that takes account of the continual threats to face that politicians encounter in political interviews. We believe it also makes more easily readable Aristotle's eternally unclear delineation, but essential relationship, of politics, rhetoric and ethics within the ideals of parliamentary democracy in the Western World.

\section{Notes}

1. That is, 24 hours a day, 7 days a week news coverage.

2. Like all matters and manners philosophic, discussion and disputation have unsurprisingly marked rhetoric's history. For example, Atherton (1988) regards Stoic rhetoric to be a failure, mainly because it shared Plato's view that the Dialectic could more correctly say what is true and what is fitting. Rhetoric in the $20^{\text {th }}$ Century has been subject to disagreement and disputation. Similarly, in the ancient world, Aristotle opposed Plato (and, hence, the Stoics) on the dialectic/rhetoric relationship (Ricoeur, 1981); Aristotle, and Plato particularly (Russell, 1967), scorned Isocrates for teaching oratory according to a narrow, four-part syllabus consisting only of 'proem, narration, proofs, and epilogue' (Solmsen, 1941); and Isocrates (like Plato) was opposed to the teaching motives of the Sophists (Wilcox, 1945).

3. Evans had to admit that he did have a sexual relationship with Cheryl Kernot, the Democrat defector to the Labor Party, when journalist Laurie Oakes criticized Kernot for failing to mention this in her 2002 biography.

\section{References}

ABC News (2005, December 7): “Embattled Nuttall quits Qld Cabinet”. Retrieved December 14, 2005 from URL: http://www.abc.net.au/news/newsitems/200512/s1526150.htm.

Adkins, Barbara (1992): "Arguing the point: The management and context of disputatious challenges in radio current affairs interviews". Australian Journalism Review 14(2): 37-49.

Ashley, James (2001, October 15): "Why spin is having a very good war". New Statesman, 8.

Atherton, Catherine (1988): "Hand over fist: The failure of stoic rhetoric". The Classical Quarterly 38(2): 392-427.

Atkinson, J. Maxwell (1984): Our Masters'Voices: The Language and Body Language of Politics. New York: Methuen.

Barthes, Roland (1988): "The old rhetoric: An aide-memoire". In R. Howard, ed., The Semiotic Challenge. Oxford: Blackwell, 11-94.

Bauman, Zygmund (1999): In Search of Politics. Oxford: Polity Press.

Bird, S. Elizabeth and Robert W. Dardennes (1988): "Myth, chronicle and story: Exploring the narrative qualities of news". In D. Berkowitz, ed., Social Meanings of News: A Text-Reader. 
Thousand Oaks, Calif.: Sage Publications, 333-350

Boulton, Adam (2001, September 23): "Bush and Blair: A very one-sided special relationship", Sunday Business, 1 .

Bourdieu, Pierre (1991): Language and Symbolic Power. Cambridge: Polity Press.

Bright, Robert, Elaine Coburn, Julie Faye, Derek Gafijczuk, Karen Hollander, Janny Jung and Helen Syrmbos. (1999): "Mainstream and marginal newspaper coverage of the 1995 Quebec Referendum: An inquiry into the functioning of the Canadian public sphere". The Canadian Review of Sociology and Anthropology 36(3): 313-330.

Budiansky, Stephen (1995): “The media's message”. U.S. News \& World Report 118(1): 45-47.

Buer, Lars (2002): "What have public affairs and advertising got in common". Journal of Public Affairs 2(4): 293-295.

Bull, Peter (1998): "Equivocation theory and news interviews". Journal of Language and Social Psychology 17(1): 36-51.

. (2000): "Equivocation and the rhetoric of modernization: An analysis of televised interviews with Tony Blair in the 1997 British General Election”. Journal of Language and Social Psychology 19(2): 222-247.

Bull, Peter and Kate Mayer (1993): "How not to answer questions in political interviews". Political Psychology 14(4): 51-66.

Bull, Peter, Judy Elliott, Derrol Palmer and Libby Walker (1996): "Why politicians are three-faced: The face model of political interviews". British Journal of Social Psychology 35(2): 267-284.

Burke, Kenneth (1969): A Rhetoric of Motives. New York: University of California Press.

Christians, Clifford G., Kim B. Rotzoll and Mark Fackler (1987): Media Ethics: Cases and Moral Reasoning (2nd ed.). New York: Longman.

Cohen, Nick (2001, "Not spinning, but drowning". New Statesman 14(644): 16-8.

Coleman, Cynthia-Lou (1997): "Science, technology and risk coverage of a community conflict". In D. A. Berkowitz, ed., Social Meanings of News: A Text-Reader. Thousand Oaks, California: Sage Publications, 483-496.

Comrie, Margie (1999): “Television news and broadcast deregulation in New Zealand". Journal of Communication 49(2): 42-54.

Dasenbrock, Reed Way (1987) "J. L. Austin and the articulation of a new rhetoric". College Composition and Communication 38(3): 291-305.

Davis, Steve (2002, July 5): Evans: "I lied to save my family, marriage". The Australian, 1.

"Dealing with the Media", (1996, August 27): The Cutting Edge, SBS TV.

de Certeau, Michel (1985): "The jabberings of social life”. In M. Blonsky, ed., On Signs. Oxford: Johns Hopkins University Press, 146-154.

De Luca, Kevin M and Jennifer Peeples (2002): "From public sphere to public screen: Democracy, activism, and the 'violence' of Seattle". Critical Studies in Media Communication 19(2): $125-151$.

Die-Zeit (2003): “German Commentary Says Tony Blair 'May Have the Worst Behind Him'”. BBC Monitoring. Retrieved November 11, 2003, from http://web.lexisnexis.com/universe/document?_m=4f01fb80f32d 5244808 ce14127587782 \&_docnum=2\&wchp=dGLbVlb-zSkVA\&_md5=1d766dea 7d811806b2272118bf57be41.

Dyer, R.R. (1990): "Rhetoric and intention in Cicero's Pro Marcello". The Journal of Roman Studies 80: 17-39.

Fairclough, Norman (1989): Language and Power. London: Longman.

Farr, Michael (2005, May 2): “'I'm not going' words took Howard by surprise, too". The Daily Telegraph, 3. 
Frank, David A. (1998): "Dialectical rapprochement in the new rhetoric". Argumentation and Advocacy 34(3): 111-126.

Franklin, Bob (1997): Newszak and News Media. London: Arnold.

Franklin, Matthew and Chris Griffith (2002, July 3): "ALP to expel prisoner D'Arcy". Courier Mail, 3.

Gardels, Nathan (1995): "Is there a liberal bias in the media?" New Perspectives Quarterly 12(2) 23-25.

Gottliebsen, Robert (2001, July 2): "If you liked BAS, you'll love the new act". The Australian, 36.

Gunn, Joshua (2003): "Refiguring fantasy: Imagination and its decline in U.S. rhetorical studies". Quarterly Journal of Speech 89(1): 41-59.

Hansard (2003, November 24): Senate Hansard: Fortieth Parliament, fifth session-sixth period, 17531. From http://www.aph.gov.au/hansard/senate/dailys/ds241103.pdf.

Heritage, John (1985): "Analysing news interviews: Aspects of the production of talk for an overhearing audience". In T. A. van Dijk, ed., Handbook of Discourse Analysis. London: Academic Press, 95-119.

. (1997): "Conversational analysis and institutional talk: Analysing data”. In D. Silverman, ed., Qualitative Research: Theory, Method and Practice. London: Sage, 161-182.

Heritage, John and David Greatbatch (1986): "Generating applause: A study of rhetoric and response at party political conferences". American Journal of Sociology 92(1): 110-157.

. (1991): "On the institutional character of institutional talk: The case of news interviews". In D. Boden and H. Zimmerman, eds., Talk and Social Structure: Studies in Ethnomethodology and Conversation Analysis. Oxford: Polity Press, 93-137.

Heritage, John and Andrew L. Roth (1995): "Grammar and institution: Questions and questioning in the broadcast news interview". Research on Language and Interaction 28(1): 1-60.

Holtz-Bacha, Christina and Pippa Norris (2001): "'To entertain, inform, and educate': Still the role of public television”. Political Communication 18(2): 123-140.

Honeycutt, Leonard (2001): Aristotle's Rhetoric. Retrieved July 9, 2004, from www.Public.iastate.edu/ honey1/Rhetoric/rhet1-3.html.

Hurd, Ian (2002): "Legitimacy, power, and the symbolic life of the UN Security Council". Global Governance 8(1): 35-61.

Hvitfelt, H. (1994): "The commercialization of the evening news: Changes in narrative technique in Swedish TV news". Nordicom Review 2: 33-41.

Jenlink, Patrick M. and Bela H. Banathy (2002): "The Agora project: The New Agoras of the twentyfirst century". Systems Research and Behavioral Science 19(5): 469-483.

Just, Marion and Rosalind Levine (2001): "News for sale". Columbia Journalism Review 40(4): 2-3.

Kelly, Fran (2002): "Crean bashing weighs down opposition leader". 7.30 Report, ABC TV. Retrieved June 27, 2002, from http://www.abc.net.au/7.30/s593170.htm.

Kelly, Paul (2005, May 4): "Partnership in tatters". The Australian, 15.

Kennedy, George A. (1972): The Art of Rhetoric in the Roman World, 300 B.C.-A.D. 300. Princeton: Princeton University Press.

Kirk, Alexander (2002): "Meg Lees speaks about Democrats leadership". The World Today, ABC Radio. Retrieved July 15, 2002, from http://www.abc.net.au/worldtoday/s608437.htm.

Lenert, Edward M. (1998): “A communication theory perspective on telecommunication policy". Journal of Communication 48(4): 3-23.

Lessig, Lawrence (2001): “Privacy and attention span”. Georgetown Law Journal 89(6): 2063-2072.

Levasseur, David G. and Kevin W. Dean (1996): "The Dole humor myth and the risk of recontextualizing rhetoric". The Southern Communication Journal 62(1): 56-72. 
Levin, Al (2002): "The classic squeeze play is on for upstate business". Syracuse Business 22(5): 1. Machill, Marcel (1999): "The effect of the commercialization of Swedish television on journalistic culture”. Press/Politics 4(2): 103-111.

MacIntyre, Iain (2001, October 24): "I reserve the right to complain", Evening Post, 14.

Maley, William (2004, July 15): "Tough words, limited action on terrorism". Sydney Morning Herald, 17.

Mander, Mary S. (1999): Framing Friction: Media and Social Conflict. Urbana: University of Illinois Press.

Marr, David (2003): "Death in Baghdad". Media Watch, ABC TV. Retrieved April, 15, 2003, from http://www.abc.net.au/mediawatch/transcripts/s832032.htm.

McGee, M. C. and Lyne, J. R. (1987): "What are nice folk like you doing in a place like this?". In J. S. Nelson, A. Megill and D. N. McCoskey, eds., The Rhetoric of the Human Sciences: Language and Argument in Scholarship and Public Affairs. Wisconsin: University of Wisconsin Press, 381-393.

McGrath, Catherine (2003): "Vanstone speaks about asylum situation". AM, ABC Radio. Retrieved

May 14, 2004, from http://www.abc.net.au/am/content/2003/s988044.htm.

McKinnon, Michael (2002, July 27): "Speed camera claims exposed". Courier Mail, 1.

Meltzer, Bernard N. (2003): "Lying: Deception in human affairs". The International Journal of Sociology and Social Policy 23(6/7): 61-79.

Milne, Glenn (2005, May 2): "PM's loose talk sparks tensions". The Australian, 9.

Mooney, Clive (2000, November 6): "The virtual campaign". The American Prospect, 36-39.

Nybakken, Oscar E. (1939): "Humanitas Romana”. Paper presented to transactions and proceedings of the American Philology Society, Iowa, 396-413.

O'Brien, Kerry (2002): "Stott Despoja moves to squash leadership questions". 7.30 Report, ABC TV. Retrieved July 17, 2003, from http://www.abc.net.au/7.30/s478909.htm.

O'Connor, Gavin (2002): “Tuckey must go for drink-driving comments". Australian Labor Party news release. From http://www.alp.org.au/media/0602/gomstmg260602.html.

O'Dair, S. (2000): “Teaching Othello in the schoolhouse door: History, Hollywood, heroes". The Massachusetts Review 41(2): 215-236.

O'Regan, Mick (2002): “The art of the interview”. ABC Radio National. Retrieved June 6, 2003, from http://www.abc.net.au/rn/talks/8.30/mediarpt/stories/s555025.htm.

Peters, John Durham (1990): "Rhetoric's revival, positivism's persistence: Social science, clear communication, and the public sphere". Sociological Theory 8(2): 224-31.

Pockley, Peter (2002): PP. Australasian Science 23(5): 45.

Potter, Jonathan (1997): "Discourse analysis as a way of analysing naturally occurring talk". In D. Silverman, ed., Qualitative research: Theory, method and practice London: Sage, 144-160.

Pusey, Michael (1997): "Inside the minds of middle Australia". Australian Quarterly 69(4): 14-21.

"Regional Aust warming to Telstra sales pitch: Vaile" (2002): ABC Radio News Retrieved July 22, 2002, from http://www.abc.net.au/news/2002/07/item20020721114525_1.htm.

Remer, Gary (1999): "Political oratory and conversation: Cicero versus deliberative democracy". Political Theory 27(1): 39-64.

Ricoeur, Paul (1981): The Rule of Metaphor: Multi-Disciplinary Studies of the Creation of Meaning in Language. Toronto: University of Toronto Press.

Ridley, F. F. (1998) “Crusaders and politicians”. Parliamentary Affairs 51(3): 309-313.

Roth Andrew L. and David Olsher (1997): "Some standard uses of "what about'-Prefaced interrogatives in the broadcast news interview". Issues in Applied Linguistics 8(1): 3-25.

Russell, D. A. (1967): "Rhetoric and criticism". Greece \& Rome 4(2): 130-144. 
Ryan, Kelly (2003, August 9): "Kew demands ignored". Herald Sun, 9.

Scheuer, Jeffrey (2001): The Sound Bite Society: How Television Helps the Right and Hurts the Left. New York: Routledge.

Schnee, Walter (2001): "Nationalism: A review of the literature". Journal of Political and Military Sociology 29(1): 1-18.

Schulberg, Budd (1957): A Face in the Crowd (film), E. Kazan (Dir.). Los Angeles.

Sheehan, Paul (2003): The Electronic Whorehouse, Sydney: Pan McMillan.

Sihler, E. G. (1920): "Quintilian of Calagurris”. The American Journal of Philology 41(3): 205-222.

Solmsen, Friedrich (1941): "The Aristotlean tradition in ancient rhetoric". The American Journal of Philology 62(1): 35-50.

Steinfels, Margaret O’Brien (2000): "Primary politics". Commonweal 127(5): 5-6.

"The world needs America to choose Obama", (2008. November 1): The Age, 10.

Tingle, Laura (2003, November 25): "Senate vetoes excise of islands from migration zone". Australian Financial Review, 5.

Tinkler, John F. (1995): Cicero on the Genres of Rhetoric. Retrieved July 14, 2004, from www.towson.edu/ tinkler/reader/ cicero.html.

Waddell, Neal and Bernard McKenna (forthcoming): "A typology of political nonpersuasion". Australian Journal of Communication.

Warnick Barbara and Susan Kline (1992): "The new rhetoric's argument schemes: A rhetorical view of practical reasoning". Argumentation and Advocacy 29(1): 1-15.

Watson, Don (2003): Death Sentence: The Decay of Public Language. Milsons Point, NSW: Random House.

Wilcox, Stanley (1945): “Isocrates' fellow-rhetoricians”. The American Journal of Philology 66(2): 171-186.

Wordsworth, Chris (2005, December 9): "Nuttall apologises and escapes criminal prosecution". From http://www.abc.net.au/pm/content/2005/s1527962.htm.

Yaxley, Louise (2002): "PM winds up European tour". AM, ABC Radio. From http://www.abc.net.au/am/s605168.htm. 